\title{
Revitalisasi pada Koperasi Unit Desa Berstatus Tidak Aktif: Studi Kasus di Kabupaten Pati
}

\author{
Jatmiko Wahyudi \\ Aeda Ernawati \\ Siti Qorrotu Aini
}

Litbang, Badan Perencanaan Pembangunan Daerah Kabupaten Pati, Indonesia

Korespondensi penulis: jatmiko.mil@gmail.com

\begin{abstract}
Revitalization is one of the government programs to re-empower rural cooperative (KUD) in Indonesia. Revitalization for inactive KUD has the purpose to reactivate KUD although the outcome is highly dependent on the conditions of the KUD as well as the internal support of the KUD. This study was conducted in two inactive KUDs in Pati Regency, Central Java namely KUD Sedyo Rukun Juwana and KUD Sukolilo. The research uses a qualitative approach with a case study design. Interviews and focus group discussion (FGD) was performed to collect data. The study aims to describe the conditions and the implementation of a revitalization program in both $K U D$. The results showed that both KUDs do not play a role as cooperative anymore. One of the indicators is that both KUDs has not carried out annual member meetings (RAT) for more than three years. Revitalization of KUD Sedyo Rukun Juwana was conducted by reorganizing and strengthening institutions through RAT. Conversely, the activation of KUD Sukolilo is nearly possible due to the complexity of the problem within the KUD. Liquidation of KUD Sukolilo can be an option to make clear the status of KUD. However, from a legal perspective, KUD Sukolilo cannot be dissolved because they experienced an inability to pay bad credit from the government.
\end{abstract}

Keywords: Rural cooperative; Revitalization; Inactive cooperative.

\begin{abstract}
Abstrak. Revitalisasi koperasi merupakan program pemerintah untuk membangkitkan kembali eksistensi koperasi unit desa (KUD). Revitalisasi koperasi pada KUD tidak aktif diarahkan agar KUD tersebut dapat aktif kembali meskipun hasil akhir revitalisasi sangat tergantung pada kondisi KUD dan dukungan internalnya. Penelitian ini dilakukan pada dua KUD yang berstatus tidak aktif di Kabupaten Pati, Provinsi Jawa Tengah, Indonesia, yaitu KUD Sedyo Rukun Juwana dan KUD Sukolilo. Penelitian ini menggunakan pendekatan kualitatif dengan disain studi kasus. Data diperoleh dengan menggunakan metode wawancara dan diskusi kelompok terfokus (FGD). Penelitian ini bertujuan untuk mengetahui gambaran kondisi KUD tidak aktif yang menjadi obyek penelitian ini dan pelaksanaan revitalisasi pada KUD tersebut. Hasil penelitian ini menunjukkan bahwa secara kelembagaan kedua KUD tersebut tidak menunjukkan eksistensi sebagai sebuah koperasi. Salah satu indikasinya adalah kedua KUD tidak
\end{abstract}


melaksanakan rapat anggota tahunan (RAT) lebih dari tiga tahun. Revitalisasi KUD Sedyo Rukun Juwana dilakukan dengan reorganisasi, penguatan kelembagaan, dan keanggotaan melalui pelaksanaan RAT. Sebaliknya, pengaktifan KUD Sukolilo sulit dilakukan karena kompleksitas permasalahan pada KUD tersebut. Secara teoretis, KUD Sukolilo layak dibubarkan agar status KUD menjadi jelas secara hokum. Namun, pembubaran KUD Sukolilo belum dapat dilakukan, karena KUD tersebut masih memiliki tunggakan kredit usaha tani.

Kata kunci: Koperasi Unit Desa (KUD); Revitalisasi; Koperasi tidak aktif.

Article Info:

Received: July 24, $2020 \quad$ Accepted: November 5, $2020 \quad$ Available online: February 16, 2021

DOI: http://dx.doi.org/10.30588/jmp.v10i2.724

\section{LATAR BELAKANG}

Koperasi Unit Desa (KUD) memainkan peranan penting dalam pengembangan ekonomi perdesaan, khususnya di sektor pertanian terutama di era pemerintahan orde baru. Catatan sejarah menunjukkan bahwa KUD mengalami masa kejayaan pada kurun waktu tahun 1973-1997 (Suradisastra, 2006). Saat itu, KUD menjadi mitra pemerintah dan mitra petani. Keberadaan KUD menjadi solusi bagi petani agar mereka terhindar dari permainan harga para tengkulak maupun kredit dengan bunga tinggi (Wiguna \& Sukadana, 2018). Sistem pengelolaan koperasi yang berasaskan kekeluargaan, gotong royong, dan menjunjung tinggi prinsip demokrasi sangat sesuai untuk dikembangkan di perdesaan.

Tumbangnya pemerintahan orde baru memberikan dampak negatif bagi perkembangan KUD. Jumlah KUD mengalami penurunan secara signifikan dan berdampak pada penurunan kontribusi KUD di sektor pertanian (Suradisastra, 2006). Kemunduran KUD patut disayangkan, karena pada dasarnya KUD memiliki peran yang sangat penting sebagai lembaga sosial ekonomi perdesaan. KUD yang berkinerja baik terbukti mampu memberikan kontribusi nyata terhadap pembangunan daerah, penyerapan tenaga kerja, dan kesejahteraan anggota (Yolandika, Lestari \& Situmorang, 2015).

Pada umumnya, fenomena kemunduran KUD terjadi di Indonesia dan di Kabupaten Pati pada khususnya. Saat ini, hanya sedikit KUD yang mampu bertahan dan menunjukkan kinerja keuangan yang baik. KUD mengalami kesulitan untuk bersaing dengan kompetitor bermodal kuat dan mengalami hambatan untuk mengakses kredit bank guna memperkuat permodalan mereka (Suyono, Rusmana \& Riswan, 2019). Sebagai contohnya, dari 23 KUD pangan di Kabupaten Pati, hanya satu KUD yang masih mampu menjalankan fungsinya sebagai distributor pupuk bersubsidi (Wahyudi, 2017).

Kemunduran maupun ketidakaktifan KUD berpotensi memberikan akibat buruk pada kesejahteraan petani. Sulitnya memperoleh akses pada kredit permodalan dengan syarat yang mudah dan bunga ringan merupakan salah satu akibat negatif kemunduran KUD. Petani rentan terperangkap pada jeratan hutang dari rentenir maupun lembaga keuangan yang memberikan pinjaman dengan bunga tinggi. Fungsi KUD yang digantikan oleh individu maupun badan usaha dengan modal lebih kuat juga berpotensi 
menyebabkan terjadinya permainan harga sarana produksi pertanian maupun produk pasca panen yang merugikan petani (Wahyudi, 2017). Koperasi, khususnya KUD, didirikan sebagai bentuk perlawanan pada sistem ekonomi kapitalis yang condong pada pemodal kuat. KUD merupakan suatu usaha bersama dengan ciri khas dual identity bagi anggotanya, yaitu anggota koperasi merupakan pemilik sekaligus pelanggan koperasi tersebut. Dengan konsep ini, anggota KUD memiliki kontrol agar KUD tidak hanya berorientasi memaksimalkam keuntungan dalam usahanya, tetapi KUD juga harus memperhatikan kemampuan anggotanya sebagai pelanggan.

Revitalisasi merupakan sebuah upaya pemerintah untuk membangkitkan kembali sektor koperasi pada umumnya dan KUD pada khususnya, sebagaimana tertuang dalam Peraturan Menteri Koperasi dan Usaha Kecil dan Menengah (UKM) Nomor 25/Per/ M.KUKM/IX/2015. Tujuan revitalisasi adalah mengaktifkan kembali koperasi yang tidak aktif dan mengembangkan koperasi aktif menjadi koperasi yang lebih besar (Kementerian Koperasi dan UKM, 2015). Revitalisasi koperasi yang aktif berbeda pendekatannya dengan koperasi yang tidak aktif. Hal ini disebabkan kondisi pada kedua kategori koperasi tersebut berbeda. Namun, secara prinsip konsep revitalisasi menekankan bahwa koperasi merupakan sasaran sekaligus sebagai pelaku revitalisasi. Dengan kata lain, berkembang tidaknya atau bahkan hidup matinya koperasi tergantung pada kemauan dan semangat internal koperasi.

Penelitian dengan mengambil obyek kajian KUD aktif telah banyak dilakukan. Beberapa penelitian-penelitian tersebut antara lain oleh Batubara, Iskandar, dan Rianti (2018); Eliyawati, Sutjipta, dan Putra (2016); dan Yolandika, Lestari, dan Situmorang (2015). Namun, penelitian mengenai KUD yang tidak aktif belum banyak dilakukan. Dalam penelitiannya, Putra dan Warsono (2016) menganalisis koperasi tidak aktif, tetapi mereka tidak membahas KUD secara khusus, sehingga hasil penelitian tersebut tidak memberikan gambaran dan permasalahan yang terjadi pada KUD tidak aktif. Secara legal formal, koperasi dinyatakan tidak aktif apabila tidak melaksanakan rapat anggota tahunan (RAT) selama tiga tahun dan atau tidak menjalankan usahanya (Kementerian Koperasi dan UKM, 2015).

Tidak dilaksanakannya RAT oleh KUD dapat disebabkan oleh alasan yang berbeda-beda terkait dengan kondisi dan kompleksitas permasalahan pada KUD-KUD yang juga berbeda. Oleh karena itu, penelitian mengenai KUD yang tidak aktif perlu dilakukan untuk memperoleh gambaran riil tentang KUD tersebut sebagai titik awal revitalisasi oleh pihak terkait. Dari uraian tersebut, penelitian ini bertujuan untuk mendiskripsikan kondisi KUD-KUD yang tidak aktif di Kabupaten Pati, Jawa Tengah, serta menganalisis pelaksanaan revitalisasi pada KUD-KUD tersebut.

\section{KAJIAN TEORITIS}

\section{Sejarah KUD}

Sebelum munculnya KUD, di wilayah perdesaan sudah tumbuh koperasi-koperasi tani (Koptan) maupun koperasi-koperasi desa (Kopdes). Pembentukan KUD tidak lepas dari kebijakan pemerintah di sektor pertanian dalam rangka stabilitas pengadaan dan harga pangan atau beras (Hermawan, 2016). Di Indonesia, beras bukan hanya menjadi komoditas pertanian, tetapi beras juga berperan besar dalam mendukung kestabilan sosial dan politik. Untuk menjamin terlaksananya program peningkatan produksi perta- 
nian, khususnya produksi pangan (beras) secara efektif dan efisien, Presiden menerbitkan Instruksi Presiden (Inpres) nomor 4/1973 tentang unit desa. Menurut Inpres nomor 4/1973 tersebut, unit desa merupakan suatu kesatuan agro ekonomis dari masyarakat desa dalam suatu wilayah yang didefinisikan sebagai satu kesatuan sawah dengan irigasi teknis yang meliputi areal 600-1000 Ha. Pada wilayah unit desa harus dibentuk Badan Usaha Unit Desa (BUUD)/Koperasi Unit Desa (KUD) yang merupakan salah satu unsur unit desa yang bertugas melaksanakan fungsi pengolahan dan pemasaran hasil produksi pertanian.

Melalui Inpres Nomor 2/1978, pemerintah berupaya untuk mengembangkan KUD dengan cara mengubah KUD dari koperasi pertanian (single-purpose) menjadi koperasi serba usaha (multi-purposes). Berdasarkan Inpres tersebut, KUD memiliki fungsi antara lain: (a) perkreditan; (b) penyediaan dan penyaluran sarana-sarana produksi, barangbarang keperluan sehari-hari, dan jasa-jasa lainnya; (c) pengolahan dan pemasaran hasil produksi; dan (d) kegiatan perekonomian lainnya. Perubahan fungsi KUD menjadi koperasi serba usaha merupakan konsekuensi logis dari meleburnya berbagai koperasi di perdesaan sekaligus mengakomodasi beragamnya kebutuhan masyarakat. Periode tahun 1973-1978 merupakan periode dengan perkembangan KUD tertinggi, yaitu tingkat pertumbuhan sebesar $88,23 \%$. Kondisi tersebut berbanding terbalik dengan jumlah koperasi non-KUD yang mengalami penurunan sebesar 26,27\% (Suradisastra, 2006). Hal ini merupakan konsekuensi logis dari proses peleburan/amalgasi koperasikoperasi di perdesaan menjadi KUD.

Sejak kemunculannya pada tahun 1973, jumlah KUD terus mengalami peningkatan dari tahun ke tahun hingga mencapai titik balik pada tahun 1997. Terjadinya krisis ekonomi pada tahun 1997 dianggap sebagai penyebab terjadinya penurunan jumlah KUD untuk pertama kalinya, yaitu dari 9.635 KUD pada tahun 1997 menjadi 9.216 KUD pada tahun 1998 (Suradisastra, 2006). Jumlah KUD semakin mengalami penurunan terutama setelah diterapkannya kebijakan pencabutan subsidi dan liberalisasi ekonomi yang menjadi syarat untuk mendapatkan pinjaman siaga (stand-by credit) dari International Monetary Fund (IMF).

Salah satu dampak kerjasama dengan IMF adalah diterbitkannya Inpres nomor 18/1998 yang memberi keleluasaan kepada masyarakat untuk mendirikan koperasi sesuai aspirasi dan kebutuhan untuk mengembangkan kegiatan usahanya. Sejak saat itu, KUD tidak lagi menjadi satu-satunya koperasi di perdesaan. Pemberlakuan Inpres nomor 18/1998 berdampak pada pesatnya peningkatan jumlah koperasi non-KUD dan penurunan jumlah KUD. Jumlah koperasi non-KUD meningkat hampir dua kali lipat hanya dalam waktu sekitar dua tahun (1998-2000), sedangkan jumlah KUD mengalami penurunan sekitar 25\% (Suradisastra, 2006).

Pencabutan subsidi dan liberalisasi ekonomi menyebabkan KUD tidak dapat bertahan dalam persaingan bebas dan mengalami kesulitan dalam menjalankan usahanya. Penyusutan fasilitas dari pemerintah berupa dana kredit untuk pangan, pupuk, dan bibit merupakan dampak terberat yang dirasakan KUD-KUD pasca keluarnya regulasi yang mencabut hak monopoli KUD (Wahyudi, 2017). Tidak adanya fasilitas kredit bagi KUD, misalnya dalam distribusi pupuk, menyebabkan KUD kalah bersaing dengan distributor non-KUD yang bermodal lebih kuat. KUD kehilangan pendapatan utamanya yang berasal dari distribusi pupuk akibat tidak mampu mempertahankan posisinya sebagai distributor pupuk dan hanya mampu bertindak sebagai pengecer. 


\section{Revitalisasi Koperasi}

Menurunnya kontribusi koperasi, khususnya KUD, telah lama menjadi perhatian pemerintah. Pada era pemerintahan Presiden Susilo Bambang Yudhoyono, pemerintah melalui Menteri Negara Koperasi dan UKM telah menerbitkan Peraturan Menteri Negara Koperasi dan Usaha Kecil dan Menengah Republik Indonesia (Permen Koperasi dan UKM) nomor 01/PER/M.KUKM/I/2013 tentang pedoman revitalisasi koperasi. Terbitnya peraturan ini bertujuan untuk memberikan pedoman terhadap langkahlangkah yang harus dilakukan oleh semua pihak terkait revitalisasi koperasi. Peraturan Menteri (Permen) yang terbit sekitar satu tahun sebelum pemerintahan Susilo Bambang Yudhoyono berakhir tersebut menyebabkan implementasi peraturan ini tidak berjalan efektif.

Pada tahun 2015, satu tahun sejak berjalannya Kabinet Kerja di bawah kepemimpinan Presiden Joko Widodo, Permen Koperasi dan UKM nomor 25/Per/M.KUKM/IX/ 2015 tentang revitalisasi koperasi diterbitkan dan sekaligus mencabut Permen Koperasi dan UKM nomor 01/PER/M.KUKM/I/2013 sebelumnya. Beberapa perbedaan substansi kedua Peraturan Menteri tersebut menunjukkan bahwa kedua pemerintahan memiliki cara pandang yang berbeda terhadap keberadaan koperasi. Perbedaan tersebut meliputi: (1) penempatan internal koperasi sebagai aktor utama revitalisasi sebagaimana tercermin dalam definisi revitalisasi koperasi; (2) proses revitalisasi meliputi identifikasi awal, langkah-langkah, dan evaluasi; dan (3) peran pemerintah pada proses revitalisasinya.

Menurut Suryaningsum, Effendi, dan Gusaptono (2017), revitalisasi merupakan upaya untuk memberdayakan atau memajukan kembali sesuatu yang mengalami kemunduran. Hal ini berarti revitalisasi koperasi dapat diartikan sebagai upaya untuk memberdayakan atau memajukan kembali suatu koperasi yang saat ini mengalami kemunduran. Sementara itu, Permen Koperasi dan UKM nomor 01/PER/M.KUKM/I/ 2013 mendefinisikan revitalisasi koperasi sebagai rangkaian kegiatan yang diselenggarakan oleh pemangku kepentingan terkait untuk menata kelembagaan dan memperkuat usaha koperasi. Peraturan terbaru terkait hal itu adalah Permen Koperasi dan UKM nomor 25/Per/M.KUKM/IX/2015 yang mendefinisikan revitalisasi koperasi dengan lebih sederhana sebagai rangkaian kegiatan yang diselenggarakan oleh koperasi yang mengupayakan agar koperasi tidak aktif dapat diaktifkan kembali dan koperasi yang aktif menjadi lebih besar (Kementerian Koperasi dan UKM, 2015).

Regulasi tentang revitalisasi koperasi yang berlaku saat ini menempatkan koperasi tidak hanya berfungsi sebagai obyek revitalisasi, tetapi koperasi juga menjadi subyek (aktor) revitalisasi. Pemerintah meyakini bahwa permasalahan ada di dalam koperasi. Oleh karena itu, pihak internal koperasi yang meliputi pengurus, pengawas, karyawan, dan anggota merupakan pihak yang mampu menyelesaikan masalah tersebut sendiri. Kebijakan yang diambil pemerintah saat ini adalah menegaskan revitalisasi koperasi bersifat bottom up. Artinya, revitalisasi koperasi harus dilakukan oleh masyarakat sendiri, yaitu pihak internal koperasi. Pemerintah berperan mendukung kegiatan revitalisasi dalam bentuk pemberian fasilitasi, konsultasi, pendampingan, monitoring, dan evaluasi terhadap koperasi yang mengupayakannya.

\section{Tahapan Revitalisasi}

Berdasarkan Permen Koperasi dan UKM nomor 25/Per/M.KUKM/IX/2015, revitalisasi koperasi dilaksanakan melalui tahapan-tahapan sebagai berikut: (1) mem- 
bentuk tim revitalisasi internal koperasi; (2) mengidentifikasi kondisi koperasi; (3) menyusun rencana strategis; dan (4) menyusun rencana aksi (Kementerian Koperasi dan UKM, 2015). Untuk memudahkan proses revitalisasi koperasi, pemerintah mengelompokkan ribuan koperasi menjadi dua kategori, yaitu koperasi aktif dan koperasi tidak aktif. Namun, koperasi-koperasi pada kategori yang sama sesungguhnya juga memiliki kondisi yang berbeda-beda pula.

Sebagian KUD yang tidak aktif masih menjalankan usaha (Dewi, Lestari,\& Adawiyah, 2017), sedangkan sebagian lain sudah tidak menjalankan usaha sama sekali (Riswan, Suyono, \& Mafudi, 2017). Kompleksitas masalah dan keterbatasan sumber daya pada KUD yang tidak aktif menyebabkan proses pengaktifan kembali tidak dapat dilakukan dalam waktu yang singkat. Tahapan revitalisasi yang telah diatur pemerintah dilakukan secara bertahap dengan memperhatikan kondisi riil koperasi dan melibatkan dukungan pihak eksternal (Herawati, 2016).

\section{METODE PENELITIAN}

Penelitian ini menggunakan pendekatan kualitatif dengan disain penelitian berupa studi kasus, yaitu studi untuk menganalisis suatu kasus yang terjadi pada waktu tertentu secara mendalam dengan cara mengumpulkan data secara lengkap dengan berbagai teknik pengumpulan data (Creswell, 2016). Penelitian ini dilaksanakan pada bulan September-November 2019. Obyek penelitian ini adalah dua KUD di Kabupaten Pati, Jawa Tengah yang berstatus tidak aktif, yaitu KUD Sukolilo dan KUD Sedyo Rukun Juwana. Obyek penelitian ditentukan setelah memperoleh informasi dari Dinas Koperasi dan Usaha Mikro Kecil dan Menengah (Dinkop UMKM) Kabupaten Pati yang menyatakan bahwa dari 23 KUD pangan di Kabupaten Pati terdapat 21 KUD berstatus aktif, sedangkan dua KUD berstatus tidak aktif, yaitu KUD Sukolilo dan KUD Sedyo Rukun Juwana.

Data yang diperoleh berupa data primer dengan metode pengumpulan data melalui teknik wawancara kualitatif (qualitative interview) yang terdiri atas teknik wawancara langsung atau berhadap-hadapan (face-to-face interview) dan wawancara dalam kelompok tertentu (focus group interview/discussion). Pertanyaan-pertanyaan dalam wawancara berupa pertanyaan tidak terstruktur dan bersifat terbuka dengan maksud agar peneliti dapat mengekplorasi opini dari informan secara mendalam. Teknik wawancara kualitatif dianggap tepat digunakan dalam penelitian ini karena dengan cara tersebut, partisipan (interviewee) dapat memberikan informasi yang terjadi pada masa lalu dan peneliti dapat mengontrol alur pertanyaan (Creswell, 2016). Penelitian ini seharusnya didukung data sekunder mengenai kondisi KUD yang biasa dilaporkan dalam RAT, misalnya kondisi keuangan, keanggotaan, dan kegiatan operasionalnya. Namun, data tersebut tidak dapat diperoleh, karena KUD yang menjadi obyek penelitian sebagai KUD tidak aktif tidak pernah menyelenggarakan RAT lebih dari lima tahun.

Semua informasi dalam penelitian ini didasarkan pada proses wawancara, sehingga kualitas informasi sangat dipengaruhi oleh daya ingat, keterbukaan, dan kejujuran informan. Peran dan kualitas informan dalam proses pengumpulan data bagi penelitian kualitatif sangat penting. Oleh karena itu, informan yang dipilih harus menguasai permasalahan yang diteliti atau memiliki pengetahuan dan keahlian pada hal-hal yang ditanyakan tersebut. Informan yang diwawancarai secara face-to-face adalah perwakilan pengurus KUD, yaitu ketua dan sekretaris KUD. Data yang terkait dengan kebijakan 
dan peran pemerintah daerah diperoleh melalui wawancara dalam kelompok tertentu (FGD). Pelaksanaan FGD diikuti oleh perwakilan perangkat daerah yang memiliki tugas pokok dan fungsi terkait KUD, khususnya program revitalisasi KUD meliputi Dinas Koperasi dan UKM, Dinas Perindustrian dan Perdagangan, Dinas Pertanian Tanaman Pangan dan Peternakan, serta Badan Perencanaan Pembangunan Daerah. Pelaksanaan FGD dilakukan sebelum dan sesudah wawancara dengan perwakilan pengurus KUD. Kegiatan FGD awal (sebelum wawancara) berfungsi sebagai studi pendahuluan untuk mengetahui gambaran umum kondisi KUD-KUD tidak aktif di Kabupaten Pati. Kegiatan FGD akhir (sesudah wawancara) berfungsi untuk mengkonfirmasi dan mendiskusikan hasil-hasil temuan di lapangan. Data yang diperoleh dianalisis secara diskriptif.

\section{HASIL DAN PEMBAHASAN}

\section{Gambaran KUD Tidak Aktif}

Pada bagian ini, informasi mengenai profil dan keberlangsungan hidup KUD sejak dulu hingga sekarang diperoleh melalui hasil wawancara dengan perwakilan pengurus KUD. Informasi ini selanjutnya menjadi bahan diskusi dan wawancara dengan dinas terkait untuk melengkapi serta mengkonfirmasi informasi tersebut. Sebagaimana KUD-KUD lain di Indonesia, KUD Sedyo Rukun dan KUD Sukolilo didirikan sebagai bentuk implementasi Inpres nomor 4 tahun 1973. Sebagai lembaga sosial ekonomi di perdesaan, KUD Sedyo Rukun dan KUD Sukolilo menjadi mitra pemerintah untuk menjalankan program-program pertanian dan turut berkontribusi pada kemajuan sektor pertanian. Pada masa kejayaannya, KUD Sedyo Rukun dan KUD Sukolilo memiliki usaha yang beraneka ragam, antara lain distributor pupuk, bibit, dan mengelola kredit bagi petani. Krisis ekonomi yang melanda Indonesia pada tahun 1997 merupakan awal kemunduran KUD. Krisis ekonomi menyebabkan daya beli masyarakat menurun dan ongkos produksi pertanian mengalami kenaikan, sehingga petani mengalami penurunan kesejahteraan. Kemampuan petani dalam menyelesaikan kredit usaha tani (KUT) juga mengalami permasalahan yang berujung pada kredit macet. Menurut penjelasan Kepala Bidang Koperasi Dinkop UMKM Kabupaten Pati, hingga saat ini KUD Sukolilo tercatat sebagai KUD dengan nilai tunggakan KUT tertinggi di Kabupaten Pati. Hal ini disebabkan KUD yang memiliki wilayah layanan dengan luas lahan pertanian terbesar di Kabupaten Pati.

Penerapan liberalisasi di sektor koperasi yang merupakan tindak lanjut kesepakatan pemerintah dengan IMF membuat KUD semakin terpuruk. Pencabutan hak monopoli dan subsidi dari pemerintah telah memukul hampir semua sektor usaha KUD. Pencabutan hak monopoli menyebabkan munculnya badan-badan usaha baru di perdesaan, termasuk diantaranya koperasi dan usaha dagang lainnya. Kehadiran badan-badan usaha baru di Kecamatan Sukolilo dan Kecamatan Juwana meningkat secara tajam. Badan-badan usaha baru tersebut sebagian dimiliki oleh masyarakat lokal (kecamatan setempat) dan sebagian dimiliki pemodal kuat dari luar kecamatan, bahkan dari luar Kabupaten Pati.

Pencabutan subsidi menjadikan koperasi harus menjalankan usaha dengan kekuatan modal sendiri tanpa dukungan pemerintah. Lemahnya manajemen dan kondisi keuangan KUD langsung dapat dirasakan pada saat itu. Posisi KUD sebagai distributor pupuk yang diambil alih oleh badan usaha lain dikarenakan KUD tersebut dinilai tidak 
memiliki kemampuan finansial untuk berperan sebagai distributor pupuk. Posisi KUD Sedyo Rukun dan KUD Sukolilo sebagai distributor pupuk bersubsidi di Kecamatan Juwana dan Sukolilo digantikan oleh badan usaha lainnya. Upaya KUD untuk meningkatkan permodalan dengan mengajukan kredit ke bank tidak dapat dilakukan, karena KUD tersebut masuk dalam daftar hitam Bank Indonesia akibat tunggakan KUT. Upaya meningkatkan permodalan dari internal anggota maupun sisa usaha juga tidak memberikan hasil yang menggembirakan.

Berdasarkan kondisi tersebut, keberhasilan KUD sebagai lembaga sosial ekonomi perdesaan bukan disebabkan kekuatan organisasi dan keandalan pengurusnya,tetapi hal itu lebih disebabkan oleh kehadiran pemerintah sebagai tiang penyangga utama.Oleh karena itu, ketika pemerintah tidak dapat mendukung KUD seperti dahulu, maka kinerja KUD langsung mengalami penurunan. Posisi KUD sebagai pemain utama perekonomian perdesaan mulai digantikan oleh lembaga ekonomi lain. Satu per satu usaha KUD mengalami penurunan dan akhirnya ditutup, karena KUD gagal berkompetisi dengan pemain-pemain baru yang bermodal lebih kuat dengan manajemen yang lebih andal. Tabel 1 menunjukkan gambaran umum KUD yang tidak aktif di Kabupaten Pati.

\section{Tabel 1. Gambaran KUD Tidak Aktif}

\begin{tabular}{lll}
\hline Indikator & \multicolumn{1}{c}{ KUD Sedyo Rukun } & \multicolumn{1}{c}{ KUD Sukolilo } \\
\hline Kelembagaan & $\bullet$ Tidak melaksanakan RAT. & $\bullet$ Tidak melaksanakan RAT. \\
& $\bullet$ Keanggotaan tidak jelas. & $\bullet$ Keanggotaan tidak jelas. \\
& $\bullet$ Kantor berlokasi tetap. & $\bullet$ Kantor tidak berlokasi tetap. \\
\hline Usaha & Jasa pembayaran listrik. & Tidak menjalankan usaha. \\
\hline Keuangan & Keuangan jasa listrik. & Tidak ada. \\
\hline
\end{tabular}

Sumber: Hasil pengolahan data (2019).

Ketika penghasilan KUD mengalami penurunan drastis,mereka tidak lagi mampu membayar pegawai, memberikan keuntungan pada anggota, maupun memupuk modal KUD. Saat ini, KUD Sedyo Rukun hanya menjalankan usaha jasa pembayaran rekening listrik. Status badan hukum yang dimilikinya dimanfaatkan untuk bekerjasama dengan pihak lain, yaitu PT PLN (Perusahaan Listrik Negara). Meskipun melakukan aktivitas ekonomi yaitu jasa pembayaran listrik, keuntungan usaha tersebut digunakan untuk membayar gaji pengelola jasa pembayaran listrik dan biaya operasional, misalnya biaya listrik, perawatan gedung, dan administrasi. Keuntungan usaha tidak ditempatkan sebagai keuntungan koperasi untuk dibagikan kepada anggota maupun pemupukan modal.

Kondisi lebih memprihatinkan dialami oleh KUD Sukolilo yang tidak menjalankan usaha apa pun. KUD Sukolilo tidak menempati lokasi yang permanen, karena KUD tidak mendapatkan penghasilan untuk memiliki atau menyewa gedung. Identitas KUD Sukolilo hanya tinggal papan nama saja yang berpindah dari satu rumah warga ke rumah warga lainnya. Meskipun tidak ada aktivitas kelembagaan maupun ekonomi, keputusan untuk tetap mempertahankan papan nama KUD lebih didasari oleh harapan akan adanya kebijakan pemerintah seperti di masa lalu, sehingga roda organisasi dan usaha KUD tersebut dapat dijalankan kembali.

Berdasarkan aspek administrasi, kedua KUD obyek penelitian ini dapat dikatakan berada pada kondisi yang sama. Salah satu dampak dari tidak terselenggaranya RAT 
adalah tidak adanya laporan keuangan yang memaparkan kondisi keuangan, aset, hutang piutang,keanggotaan, dan kepengurusan. Laporan keuangan terkini yang dimiliki KUD Sedyo Rukun hanya berisi kondisi pengelolaan usaha jasa pembayaran listrik. Berdasarkan aspek keanggotaan, tidak ada data yang pasti mengenai jumlah, mutasi, dan distribusi anggota di setiap desa yang menjadi wilayah layanan KUD. Data keanggotaan yang disampaikan informan merupakan data di masa lalu dan akurasinya sangat tergantung pada daya ingat mereka. Data terbaru mengenai jumlah anggota yang masih hidup, telah meninggal, dan berpindah domisili tidak diperoleh. Pada koperasi-koperasi yang sehat, anggota yang tidak membayar simpanan wajib dapat diberhentikan sebagai anggota koperasi. Namun, pemberhentian anggota pada KUD terutama KUD-KUD bermasalah bukanlah persoalan yang sederhana. Memberhentikan anggota berarti memutus hubungan antara anggota dengan KUD, padahal anggota yang bersangkutan memiliki tunggakan KUT yang tidak jelas bagaimana penyelesaiannya.

Pada dasarnya, anggota KUD merupakan tulang punggung organisasi,tetapi kondisi KUD saat ini menyebabkan masyarakat tidak tertarik untuk bertahan menjadi anggota KUD atau pun mendaftar menjadi anggota baru KUD. Tingkat kepercayaan masyarakat, baik anggota maupun calon anggota untuk bergabung sangat rendah. Keputusan masyarakat untuk memilih menggunakan jasa pembayaran listrik di KUD Sedyo Rukun lebih didasari pada faktor kedekatan lokasi. Para pelanggan pembayaran listrik enggan menjadi anggota KUD, karena mereka merasa tidak adanya manfaat yang jelas dengan bergabungnya mereka menjadi anggota KUD, misalnya fasilitas discount pembayaran listrik maupun pembagian sisa hasil usaha (SHU). Sebaliknya, KUD kesulitan memberikan keuntungan bagi anggotanya, karena KUD hanya menjalankan satu jenis usaha dengan pendapatan yang kecil. Selain itu, ketidakjelasan status ribuan orang yang pernah tercatat sebagai anggota KUD juga menjadi kendala yang lain.

\section{Revitalisasi}

Upaya untuk menyelamatkan KUD atau yang lebih dikenal sebagai strategi revitalisasi KUD telah lama menjadi perhatian Pemerintah Kabupaten Pati.Uraian di bagian ini menjelaskan pelaksanaan strategi dan kendala-kendala yang dihadapi untuk merevitalisasi KUD Sedyo Rukun dan KUD Sukolilo. Selanjutnya, pembahasan difokuskan pada upaya dan kebijakan pemerintah daerah untuk merevitalisasi KUDKUD yang tidak aktif tersebut.

\section{Pelaksanaan Revitalisasi}

Revitalisasi koperasi merupakan kebijakan pemerintah, sehingga informasi pelaksanaan revitalisasi banyak dimunculkan saat FGD. Pelaksanaan FGD pada saat awal penelitian menghasilkan informasi terkait kondisi KUD terkini serta pelaksanaan revitalisasi yang telah berlangsung dan rencana masa datang. Informasi yang diperoleh dari FGD menjadi dasar pertanyaan saat wawancara dengan pengurus KUD mengenai revitalisasi yang terjadi di KUD mereka dan peran dari pemerintah.

Pelaksanaan revitalisasi koperasi di Kabupaten Pati mengacu pada peraturan yang berlaku termasuk di antaranya pelaksanaan revitalisasi melalui empat tahapan revitalisasi. Revitalisasi pada koperasi tidak aktif diarahkan agar koperasi tidak aktif menjadi koperasi yang aktif. Berdasarkan regulasi, koperasi dinyatakan aktif apabila koperasi melaksanakan rapat anggota tahunan (RAT) dan atau menjalankan usahanya. Oleh karena itu, segala bentuk upaya pembenahan pada tahap awal diarahkan untuk mencukupi kebutuhan agar RAT dapat dilaksanakan. Dinas Koperasi dan UMKM 
Kabupaten Pati melaksanakan tahapan pertama revitalisasi, yaitu membentuk tim revitalisasi di internal KUD untuk mempersiapkan pelaksanaan RAT.

Revitalisasi tahap kedua adalah mengidentifikasi kondisi koperasi. Identifikasi koperasi dilakukan oleh dinas terkait dan dilanjutkan oleh tim revitalisasi. Proses identifikasi dilakukan dengan melaksanakan kegiatan bimbingan teknis (bimtek) dan pengawasan (monitoring). Kegiatan monitoring dilakukan dengan cara mendatangi KUD secara langsung dengan tujuan untuk mengetahui kondisi KUD sebagai deteksi awal permasalahan pada KUD tersebut. Kegiatan bimbingan teknis dilakukan dengan mengumpulkan perwakilan seluruh KUD. Kegiatan bimtek bertujuan untuk menguatkan KUD. Selain itu, kegiatan mengumpulkan KUD dimaksudkan agar terjadi sharing pengalaman dari KUD yang berkinerja baik.

Hasil identifikasi yang dilakukan oleh dinas terkait menunjukkan dua KUD tidak aktif memiliki keterbatasan terutama pendanaan untuk melaksanakan RAT. Solusi yang diberikan oleh Pemerintah Kabupaten Pati adalah dengan memfasilitasi pelaksanaan RAT dengan beberapa syarat. Pertama, pengurus KUD bersedia untuk melaksanakan acara tersebut. Kedua, pengurus mampu merekrut calon pengurus dan calon anggota baru. Ketiga, pengurus melakukan penataan aset dan keuangan dengan baik.

Syarat pertama dan kedua erat kaitannya dengan pembentukan tim revitalisasi (tahapan pertama revitalisasi), sedangkan syarat ketiga merupakan bentuk identifikasi kondisi yang dilakukan oleh tim revitalisasi (tahapan kedua revitalisasi). Tahapan revitalisasi ketiga dan keempat, yaitu penyusunan rencana strategis dan rencana aksi direncanakan untuk direalisasi setelah pelaksanaan RAT. Pelaksanaan tahapan revitalisasi ketiga dan keempat diharapkan dapat dilaksanakan oleh kepengurusan baru dengan pendampingan pemerintah daerah.

Pelaksanaan revitalisasi pada tahapan pertama dan kedua dapat berjalan di KUD Sedyo Rukun. Para pihak terkait meyakini bahwa target jangka pendek, yaitu pelaksanaan RAT dapat terealisasi, sehingga status KUD aktif dapat diperoleh. Pengurus KUD Sedyo Rukun memberikan respon positif terhadap rencana fasilitasi RAT oleh pemerintah. Kondisi riil di KUD Sedyo Rukun adalah keberadaan anggota KUD tidak jelas dan beberapa pengurus KUD sudah tidak aktif lagi. Oleh karena itu, tahapan pembentukan tim revitalisasi dimulai dengan rekrutmen calon pengurus maupun calon anggota KUD sebagai cikal bakal tim revitalisasi KUD. Langkah yang dilakukan pengurus lama adalah merekrut pegawai jasa pembayaran listrik sebagai calon pengurus. Para pelanggan jasa pembayaran listrik akan direkrut sebagai anggota baru KUD Sedyo Rukun. Tahapan identifikasi kondisi koperasi menjadi sasaran yang harus dilaksanakan sampai dengan pelaksanaan RAT meskipun identifikasi dilakukan secara bertahap sesuai dengan kemampuan internal KUD Sedyo Rukun yang terbatas jumlah personelnya.

Revitalisasi KUD Sukolilo tidak dapat berjalan, karena KUD tersebut tidak memiliki aktivitas sama sekali, tidak memiliki kantor yang tetap, serta pengurus maupun anggota sudah tidak jelas keberadaannya. Revitalisasi KUD dari Pemerintah Kabupaten Pati tidak diarahkan untuk memberikan anggaran bagi KUD sebagai modal usaha maupun biaya operasional kantor. Penetrasi/bantuan pemerintah terhadap KUD-KUD yang tidak aktif harus terukur dan sesuai regulasi. Pembentukan tim revitalisasi tidak dapat dilakukan, sehingga otomatis tahapan-tahapan revitalisasi berikutnya tidak dapat dilakukan. 
Berdasarkan Permenkop dan UKM nomor 25/Per/M.KUKM/IX/2015, koperasi tidak aktif yang gagal melakukan revitalisasi diarahkan untuk dibubarkan. Berdasarkan pasal 47 Undang-Undang nomor 25 Tahun 1992 tentang perkoperasian, koperasi dapat dibubarkan oleh pemerintah apabila kelangsungan hidupnya tidak dapat lagi diharapkan berdasarkan keputusan pengadilan. Putusan pailit dari pengadilan dapat menjadi dasar bagi pemerintah untuk membubarkan koperasi. Namun, kewenangan membubarkan koperasi dimiliki oleh pemerintah melalui Menteri Koperasi dan UKM. Pada praktiknya, KUD Sukolilo sebenarnya layak untuk dibubarkan, tetapi pemerintah mengambil kebijakan bahwa KUD hanya dapat dibubarkan setelah menyelesaikan semua hutang KUD kepada pemerintah (KUT). Menurut penuturan perwakilan Dinkop UMKM Kabupaten Pati bahwa upaya pemutihan hutang KUT pernah diusulkan agar permasalahan hutang KUT beserta dampaknya dapat diselesaikan, tetapi usulan tersebut ditolak oleh pemerintah pusat. Kebijakan nasional ini menjadi pedoman bagi pemerintah daerah dalam menyikapi keberadaan KUD yang tidak dapat diselamatkan lagi. Pemerintah Kabupaten Pati menempatkan KUD Sukolilo pada status quo yang berarti KUD tersebut dibiarkan sebagaimana kondisi sekarang. Pembiaran KUD Sukolilo tidak diartikan bahwa pemerintah abai dan pasif, tetapi kebijakan tersebut berdasarkan kondisi riil koperasi yang tidak mungkin diselamatkan dan kebijakan pemerintah yang tidak memungkinkan untuk membubarkan koperasi.

Regenerasi dan reorganisasi menjadi kunci dalam revitalisasi KUD yang tidak aktif. Revitalisasi organisasi KUD hanya akan berjalan apabila masyarakat, khususnya pengurus dan anggota KUD, telah direvitalisasi (Rufaidah, 2017). Regenerasi anggota adalah keanggotaan lama KUD yang mencapai ribuan anggota dan tidak jelas keberadaannya akan digolongkan sebagai anggota pasif yang tidak dikenakan hak maupun kewajiban. KUD yang direvitalisasi diharapkan mampu merekrut anggota baru dengan hak dan kewajiban yang jelas. Dukungan dari anggota merupakan faktor penting bagi eksistensi KUD, ketika kredit bank dan bantuan dana dari pemerintah sulit diperoleh. Pembelajaran yang diperoleh dari keberhasilan KUD Bahagia sebagai KUD terbaik di Kabupaten Pati adalah kemampuan KUD tersebut untuk menghimpun dana anggota. Seperti halnya KUD lain, KUD Bahagia juga kesulitan untuk mengakses kredit bank karena tunggakan KUT, tetapi kinerja KUD yang baik menyebabkan masyarakat bersedia melakukan investasi pada KUD Bahagia (Wahyudi, 2017).

Regenerasi pengurus dimaksudkan untuk mengganti pengurus KUD lama yang tidak mampu menjalankan fungsinya sebagai pengurus yang disebabkan oleh faktor usia dan faktor lainnya. Reorganisasi diartikan bahwa KUD tampil sebagai organisasi yang menjalankan usaha dengan cara merespon tatanan masyarakat maupun tatanan ekonomi yang berbeda dengan KUD di masa lalu. Kemajuan teknologi, khususnya teknologi informasi, dapat menjadi faktor penting untuk mengelola keterlibatan banyak pihak guna menunjang kegiatan revitalisasi koperasi (Suryaningsum, Effendi \& Gusaptono, 2017). Penguasaan teknologi informasi merupakan salah satu aspek penting yang harus dimiliki oleh pengurus baru. Oleh karena itu, penerapan teknologi informasi merupakan salah satu ciri perusahaan modern dan dengan penerapan teknologi informasi diharapkan memberikan dampak pada efektifitas, transparansi, dan efisiensi pada operasionalisasi KUD (Suyono, Rusmana \& Riswan, 2019). 


\section{Kendala Revitalisasi}

Secara garis besar, kendala yang dihadapi dalam merevitalisasi KUD berasal dari dua faktor, yaitu pemerintah dan internal koperasi. Kendala yang berasal dari pemerintah sendiri, antara lain mencakup keterbatasan sumber daya, regulasi, dan ego sektoral antarinstansi. Keterbatasan sumber daya yang dimiliki pemerintah meliputi sumber daya manusia dan anggaran, karena saat ini jumlah koperasi mengalami peningkatan. Peningkatan jumlah koperasi tersebut tidak hanya menyebabkan semakin bertambahnya obyek pembinaan dan pengawasan, tetapi juga penyimpangan dan penyelewengan yang dilakukan oleh oknum pengurus koperasi semakin sering terjadi. Menurut penuturan Kepala Bidang Koperasi Dinkop UMKM Kabupaten Pati, kasus hilangnya uang anggota koperasi karena dibawa lari oleh pengurusnya juga pernah terjadi di Kabupaten Pati. Oleh karena itu, anggaran dan sumber daya manusia pemerintah tidak tepat hanya difokuskan pada KUD-KUD saja, tetapi juga koperasi-koperasi lainnya.

Regulasi yang berlaku mendorong instansi pemerintah, baik pusat maupun daerah untuk mengembangkan lembaga sosial ekonomi perdesaan sendiri-sendiri. Anggaran pembangunan desa terbagi-bagi ke berbagai lembaga binaan pemerintah. Hal ini berbeda dengan kondisi pada masa orde baru yang hanya menempatkan KUD sebagai badan usaha tunggal di perdesaan dan mewajibkan semua kementerian yang memiliki program dengan sasaran perdesaan untuk menggunakan KUD saja. Pengembangan koperasi termasuk revitalisasi KUD cenderung hanya menjadi tanggung jawab Kementerian Koperasi dan UKM beserta perangkat daerah di bawahnya. Besarnya perhatian pemerintah pada pembangunan perdesaan tidak serta merta berdampak positif terhadap perkembangan KUD.

Saat ini, lembaga sosial ekonomi perdesaan banyak dikembangkan oleh perangkat daerah sebagai kepanjangan tangan program yang dijalankan kementerian vertikal, misalnya Badan Usaha Milik Desa (BUMDes), kelompok tani (Poktan), dan perkumpulan petani pemakai air (P3A). Pada gilirannya, perangkat daerah maupun kementerian terkait fokus pada penggunaan anggarannya untuk memperkuat lembaga sosial ekonomi yang menjadi binaannya. Lembaga sosial ekonomi perdesaan seperti BUMDes memiliki fungsi untuk menjalankan usaha yang sama dengan KUD. Dalam kurun waktu yang relatif singkat, BUMDes di setiap desa atau 401 desa telah berdiri di Kabupaten Pati dan pengembangannya diperkuat oleh Dinas Pemberdayaan Masyarakat Desa. Pada awalnya, lembaga-lembaga perdesaan lain, seperti Poktan dan P3A, didisain untuk mendukung peran teknis, tetapi faktanya lembaga-lembaga tersebut didorong pula untuk menjalankan usaha dalam rangka kemandirian dan kesejahteraan anggotanya.

Selain hambatan yang berasal dari eksternal KUD, pelaksanaan revitalisasi juga menemui kendala yang berasal dari internal KUD meliputi kompleksitas masalah terutama akibat tunggakan KUT, motivasi pengurus, dan regenerasi. Pelaksanaan revitalisasi membutuhkan ketersediaan infrastruktur dan anggaran yang mencukupi untuk operasional organisasi maupun menggerakkan usahanya. Tunggakan KUT menyebabkan KUD ditempatkan di dalam daftar hitam Bank Indonesia, sehingga kondisi tersebut berdampak pada sulitnya KUD memperoleh modal dari pihak luar (bank). Keterbatasan modal menyebabkan KUD kesulitan untuk mengembangkan usaha maupun menjalankan roda organisasinya. Bantuan pemerintah daerah dalam bentuk hibah maupun dana bergulir juga tidak dapat disalurkan kepada KUD tidak aktif. 
Kendala revitalisasi berikutnya yang berasal dari internal KUD adalah rendahnya motivasi pengurus untuk membangkitkan KUD kembali. Kedua KUD tidak aktif yang menjadi obyek penelitian dapat dikatakan tidak lagi memiliki anggota riil. Oleh karena itu, eksistensi pengurus menjadi hal penting untuk menggerakkan KUD maupun menjalankan revitalisasi. Salah satu indikasi rendahnya motivasi pengurus KUD adalah tidak aktifnya pengurus KUD Sedyo Rukun dan KUD Sukolilo pada kegiatan-kegiatan perkoperasian yang diselenggarakan oleh pemerintah. Rendahnya motivasi pengurus KUD Sedyo Rukun dan KUD Sukolilo diduga karena mereka telah berusia lanjut dan kompleksnya permasalahan yang mereka hadapi. Proses regenerasi pengurus maupun penambahan anggota baru relatif tidak berjalan. Generasi muda cenderung lebih memilih bergabung dengan koperasi maupun lembaga sosial ekonomi perdesaan lain yang dirasakan lebih prospektif dan memberikan manfaat yang jelas.

\section{KESIMPULAN DAN SARAN}

\section{Kesimpulan}

Keberhasilan revitalisasi KUD tidak aktif sangat ditentukan oleh kondisi internal KUD. Penelitian ini menunjukkan perbedaan kondisi dua KUD tidak aktif obyek penelitian ini yang berakibat pada proses revitalisasi pada KUD tersebut. Berbeda dengan KUD Sukolilo, KUD Sedyo Rukun masih memiliki infrastruktur yang memadai, masih menjalankan usaha, dan memiliki SDM yang menjalankan usahanya. Oleh karena itu, proses revitalisasi di KUD Sedyo Rukun dapat dilaksanakan sesuai tahapannya, sedangkan proses revitalisasi di KUD Sukolilo praktis sulit dijalankan. Regenerasi pengurus dan anggota merupakan hal penting yang harus dilakukan. Anggota KUD sebagai pemilik sekaligus pelanggan KUD (dual identity) menjadi tulang punggung utama keberlangsungan kegiatan KUD. Secara realistis, KUD Sukolilo layak untuk dibubarkan, karena KUD Sukolilo tidak dapat diharapkan keberlangsungan hidupnya. Namun, kebijakan pemerintah yang mensyaratkan pelunasan KUT menyebabkan KUD tidak mungkin untuk dibubarkan dan tetap dicatat dengan kondisi status quo, karena KUD tersebut tidak memiliki aktivitas sama sekali.

\section{Saran}

Kemajuan proses revitalisasi di KUD Sedyo Rukun perlu mendapatkan dukungan dan pendampingan Pemerintah Kabupaten Pati. Status aktif dapat segera direalisasikan melalui mekanisme RAT. Kelemahan dan keterbatasan yang dimiliki oleh KUD Sedyo Rukun sebagai KUD tidak aktif, misalnya kualitas SDM maupun minimnya permodalan perlu segera diatasi dengan bantuan pemerintah. Pemerintah perlu melakukan bimbingan teknis maupun mengikutsertakan KUD Sedyo Rukun untuk melakukan studi banding ke KUD-KUD yang kinerjanya lebih baik. Bantuan permodalan maupun pengembangan usaha perlu diupayakan melalui kerja sama dengan perangkat daerah lain maupun badan usaha lainnya.

\section{DAFTAR REFERENSI}

Batubara, M. M., Iskandar, S., \& Rianti, R. (2018). Peranan Koperasi Unit Desa (KUD) Kumbang Jaya dalam Membantu Perekonomian Petani Kelapa Sawit di Desa Sidomakmur Kecamatan Air Kumbang Kabupaten Banyuasin. Societa: Jurnal Ilmu-Ilmu Agribisnis, VII(1), 9-16. https://doi.org/10.32502/jsct.v7i1.1129. 
Creswell, R. J. (2016). Research Design: Pendekatan Metode Kualitatif, Kuantitatif dan Campuran. Yogyakarta: Pustaka Pelajar.

Depkop (2020). Undang-Undang Nomor 25 Tahun 1992 tentang Perkoperasian. Diakses tanggal 8 Oktober 2020 di

http://www.depkop.go.id/uploads/laporan/1566784877_uu_1992_25_perkoperasi an.pdf.

Dewi, V. S., Lestari, D. A. H., \& Adawiyah, R. (2017). Kinerja, Kesejahteraan Anggota, dan Strategi Pengembangan Koperasi Unit Desa. Jurnal Ilmu-Ilmu Agribisnis, 5(1), 76-83. http://dx.doi.org/10.23960/jiia.v5i1.\%25p.

Eliyawati, W., Sutjipta, N., \& Putra, S. A. (2016). Kualitas Pelayanan dan Tingkat Kepuasan Anggota Koperasi Unit Desa Suraberata Kecamatan Selemadeg Barat. Jurnal Manajemen Agribisnis, 4(1), 68-80. https://ojs.unud.ac.id/index.php/agribisnis/article/view/21477>.

Herawati, N. R. (2016). Peraturan Menteri Koperasi dan Usaha Kecil dan Menengah Republik Indonesia Nomor 25/Per/M.KUKM/IX/2015 Sebagai Upaya Pemerintah Mengembalikan Kejayaan Petani. EKOMAKS: Jurnal Ilmu Ekonomi, Manajemen, dan Akuntansi, 5(2), 58-64.

Hermawan, I. (2016). Kebijakan Perberasan Indonesia dan Solidaritas Pangan ASEAN. Politica, 7(1), 102-120.

BKPM (2020). Instruksi Presiden Republik Indonesia Nomor 4 Tahun 1973 tentang Unit Desa. Diakses tanggal 8 Oktober 2020 di https://peraturan.bkpm.go.id/jdih/userfiles/batang/InPres_4_1973.pdf.

BKPM (2020). Instruksi Presiden Republik Indonesia Nomor 2 Tahun 1978 tentang Badan Usaha Unit Desa/Koperasi Unit Desa (BUUD/KUD). Diakses tanggal 8 Oktober 2020 di https://peraturan.bkpm.go.id/jdih/userfiles/batang/InPres_2_1978.pdf

BKPM (2020). Instruksi Presiden Republik Indonesia Nomor 18 Tahun 1998 tentang Peningkatan Pembinaan dan Pengembangan Perkoperasian. Diakses tanggal 8 Oktober 2020 di https://peraturan.bkpm.go.id/jdih/front/form/14825.

Kementerian Koperasi dan UKM (2013). Peraturan Menteri Koperasi dan Usaha Kecil dan Menengah Republik Indonesia Nomor 01/PER/M.KUKM/I/2013 tentang Pedoman Revitalisasi Koperasi. Diakses tanggal 8 Oktober 2020 di http://www.depkop.go.id/uploads/tx_rtgfiles/permen_2013_01_01_pedoman_revi talisasi_koperasi_lampiran.pdf.

Kementerian Koperasi dan UKM (2015). Peraturan Menteri Koperasi dan Usaha Kecil dan Menengah Republik Indonesia Nomor 25/Per/M.KUKM/IX/2015 tentang Revitalisasi Koperasi. Jakarta: Kementerian Koperasi dan Usaha Kecil dan Menengah. Diakses tanggal 8 Oktober 2020 di http://www.depkop.go.id/uploads/tx_rtgfiles/permen_kukm_nomor_25_tahun_20 15_tentang_revitalisasi_koperasi.pdf.

Putra, A. H. P \& Warsono, H. (2016). Analisis Pelaksanaan Strategi Pengembangan Koperasi Tidak Aktif di Jawa Tengah. Journal of Public Policy and Management Review, 5(2), 527-542. https://doi.org/10.14710/jppmr.v5i2.11110.

Riswan, R., Suyono, E., Mafudi, M. (2017). Revitalization Model for Village Unit Cooperative in Indonesia. European Research Studies Journal, XX(4A), 102-123. https://doi.org/10.35808/ersj/822. 
Rufaidah, E. (2017). Pemberdayaan Perekonomian Masyarakat melalui Koperasi Unit Desa Berbasis Usaha Terbimbing. Akademika: Jurnal Pemikiran Islam, 22(02), 361-374. https://doi.org/10.32332/akademika.v22i2.824.

Suradisastra, K. (2006). Agricultural Cooperative in Indonesia. FFTC-NACF International Seminar on Agricultural Cooperatives in Asia: Innovations and Opportunities in the 21st Century. Seoul, Korea, 11-15 September, 06-1-16.

Suryaningsum, S., Effendi, M. I., Gusaptono, R. H. (2017). Revitalisasi Koperasi. Yogyakarta: LPPM UPN "Veteran” Diakses tanggal 8 Oktober 2020 di http://eprints.upnyk.ac.id/13625/2/3. Revitalisasi Koperasi.pdf.

Suyono, E., Rusmana, O. \& Riswan, R. (2019). Integrated Information System to Revitalize the Cooperatives in Banyumas. IOP Conference Series: Earth and Environmental Science, 255, 1-11. https://doi.org/10.1088/17551315/255/1/012046.

Wahyudi, J. (2017). Kontribusi Koperasi dalam Upaya Pencapaian Tujuan-tujuan Pembangunan Berkelanjutan (Studi Kasus KUD Bahagia Kabupaten Pati). Proceeding-the 6th University Research Colloquium: Seri Humaniora, Sosial, dan Agama, Universitas Muhammadiyah Magelang, 9-16.

Wiguna, P. A. \& Sukadana, I. W. (2018). Peran Koperasi Unit Desa dalam Meningkatkan Kesejahteraan Petani di Indonesia (Analisis Data Mikro). E-Jurnal Ekonomi Pembangunan Universitas Udayana, 7(1), 30-57. https://ojs.unud.ac.id/index.php/eep/article/view/35843.

Yolandika, C., Lestari, D. A. H., Situmorang, S. (2015). Keberhasilan Koperasi Unit Desa (KUD) Mina Jaya Kota Bandar Lampung Berdasarkan Pendekatan Tripartite. Jurnal Ilmu-ilmu Agribisnis, 3(4), 385-392. http://dx.doi.org/10.23960/jiia.v3i4.\%25p. 